\title{
Anatomical and clinical relevance of elongated styloid process in a sample of the Colombian population
}

\author{
BAENA-CALDAS, G. P. ${ }^{1}$, ROJAS-ZULUAGA, S. ${ }^{2}$ and PECKHAM, X. ${ }^{3,4}$ \\ ${ }^{1}$ Department of Morphology, Health Sciences Division, Universidad del Valle - Univalle, Calle 4B, 36-00, \\ Building 116, Zip Code 760001, Cali, Colombia \\ ${ }^{2}$ School of Medicine and Surgery, Universidad del Valle - Univalle, Calle 4B, 36-00, Zip Code 760001, Cali, Colombia \\ ${ }^{3}$ Science Division, Long Island University, Brooklyn, NY, United States \\ ${ }^{4}$ Biology Department, University Plaza, Brooklyn, NY, 11201, United States \\ *E-mail: gloria.baena@correounivalle.edu.co
}

\begin{abstract}
Introduction: The styloid process is a cone-shaped process of the temporal bone with a normal length of 20 to $30 \mathrm{~mm}$. It is considered "elongated" when its length is greater than $30 \mathrm{~mm}$. A temporal styloid process with a length of $25 \mathrm{~mm}$ or more may cause Eagle's syndrome, a condition characterized by multiple clinical symptoms that can be explained by the anatomical relationships of the styloid process. The length of the styloid process depends on demographic variables such as race and geographical distribution; therefore normal patterns may vary among different populations. Due to its non-specific clinical manifestations, it would be relevant to know its prevalence in a specific population. The aim of this study was to determine the frequency of styloid process elongation in a sample of the Colombian population. Material and Methods: The study was a cross-sectional, observational descriptive study. The length of 46 styloid processes from their origin to their vertex was determined in 46 hemifacial dissections. The corresponding right or left side of the head of the styloid process was also recorded. Results: The obtained average length of styloid processes was $35.1 \pm 13.2 \mathrm{~mm}$. 23 styloid processes (50\%) measured over $30 \mathrm{~mm}$, and 38 processes (82.6\%) measured $25 \mathrm{~mm}$ or more. Conclusion: Since previous reports have shown that the onset of symptoms is variable and sometimes independent of the length of the styloid process, we suggest that the angulation of the styloid process is a clinical consideration as important as the length of the styloid process.
\end{abstract}

Keywords: elongated styloid process, anatomical variation, human skull, eagle syndrome.

\section{Introduction}

Embryologically, the styloid process (SP) originates from the second pharyngeal arch or Reichert's arch, which is subdivided from dorsal to ventral into 4 regions: The tympanohyal region, which develops before birth and gives origin to the base of the styloid process; the stylohyal region, which develops after birth and gives origin to the vertex of the styloid process; the ceratohyal region, which develops in uterus and gives origin to the stylohyoid ligament and the hypohyal region that gives origin to the lesser cornu and the upper division of the hyoid bone (CHOURDIA, 2002; MOON, LEE, KWON et al., 2014).

The styloid process is derived from the Greek word Stylos meaning "pillar". It is a cone-shaped eminence of the petrous region of the temporal bone. It projects anterior to the stylomastoid foramen, lateral to the jugular fossa and carotid canal, and posterior to the petrotympanic fissure and vaginal process of the tympanic portion of the temporal bone, which partially surrounds its base. Its medial anatomical relationships are the internal jugular vein, the glossopharyngeal nerve, vagus nerve, and accessory nerve, the internal carotid artery and the carotid plexus. It is related anteriorly to the chorda tympani and laterally to the external carotid artery and the mandibular branch of the trigeminal nerve. Three muscles originate from the styloid process from its superior to its inferior end: The most superior is the styloglossus muscle, followed by the stylopharyngeal muscle, which is deeper and is related to the glossopharyngeal nerve. The stylohyoid muscle originates near the inferior end of the styloid process. Other anatomical structures that are directly related with the styloid process are the stylomandibular ligament and the stylohyoid ligament (MOON, LEE, KWON et al., 2014; SUDHAKARA-REDDY, SAI-KIRAN, SAI-MADHAVI et al., 2013; ELIMAIRI, BAUR, ALTAY et al., 2015).

The average SP is approximately $25 \mathrm{~mm}$ in length and it is considered elongated when the length is greater than $30 \mathrm{~mm}$. The prevalence of an elongated process in the general population is 4 to $52.1 \%$. When the length of the styloid process is equal or more than $25 \mathrm{~mm}$, clinical manifestations may occur and can be explained by the relationship between the styloid process and the adjacent anatomical structures (BOUZAIDI, DAGHFOUS, FOURATI et al., 2013; CULLU, DEVEER, SAHAN et al., 2013; KHANDELWAL, HADA and HARSH, 2011; MAYRINK, FIGUEIREDO, SATO et al., 2012).

Anatomical variations depend on sociodemographic factors such as age and the geographic distribution, hence the importance of knowing their prevalence in the local population. The goal of this study was to determine the frequency of elongation of the styloid process in a sample of the Colombian population and its clinical significance. 


\section{Materials and Methods}

The study was a cross-sectional, observational descriptive study. It was part of a larger project entitled "Data Systematization of the anatomical variations found in the dissection lab cadavers of the Universidad del Valle (Cali, Colombia)", which was endorsed by its Human Ethics Committe. The study population was 46 hemifaces of cadavers at the Universidad del Valle in Cali, Colombia. The main inclusion criteria were cadavers having an appropriate dissection of the cervical and parotidomasseteric regions with good access to the external base of the skull. The hemifaces with fracture of the styloid process were excluded from the study. The sex variable was excluded due to the impossibility in determining the gender in some of the isolated hemifaces.

The variables of length and laterality of the hemifaces was registered. The styloid processes were measured along their anterior border, from their origin at the external base of the skull -at the level of the vaginal process of the temporal bone- up to its vertex using a digital electronic calibrator Bulltools ${ }^{\circledR}$, with a resolution of $0.01 \mathrm{~mm} / 0.0005$ ", precision $\pm 0.02 \mathrm{~mm} / 0.001 "$ and repeatability of $0.01 \mathrm{~mm} / 0.0005 "$. In order to reduce a measuring bias, two of the investigators did random measurements and intra and interobserving testing was done in order to maximize data quality. Data was analyzed through descriptive statistics.

\section{Results}

The obtained average length of the styloid processes was $35.1 \pm 13.2 \mathrm{~mm}$ (CI 95\%; 31.3-38.9; p <0.5), with a median of $30.5 \mathrm{~mm}$ and a range of $12-68 \mathrm{~mm}$. Twenty-three styloid processes of the studied hemifaces $(50 \%)$ measured over $30 \mathrm{~mm}$, and 38 styloid processes (82.6\%) measured over $25 \mathrm{~mm}$. The styloid processes of the right side $(\mathrm{n}=22)$ had an average length of $35.6 \pm 12,5 \mathrm{~mm}$ (CI 95\%; 30.4-40.8; p <0.5), with a median of $33 \mathrm{~mm}$ and a range of $12-68 \mathrm{~mm}$; The average length of the styloid processes of the left side $(n=24)$ was $34.6 \pm 14.1 \mathrm{~mm}$ (CI 95\%; 29-40.2; p <0.5), with a median of $29.5 \mathrm{~mm}$ and a range of $18-66 \mathrm{~mm}$. The longest styloid process was $68 \mathrm{~mm}$ on the right side (Figure 1), followed by $66 \mathrm{~mm}$ on the left side (Figure 2). The shortest styloid process was $12 \mathrm{~mm}$ in length and it was found on the right side.

\section{Discussion}

The etiology of elongation of styloid process is controversial, but several causes are stipulated: genetic, embryological, ligament metaplasia, disorders of calcium metabolism, secondary ossification, trauma, degenerative changes with loss of elasticity of the soft tissues, and tendinitis of muscles associated with the process (BOUZAIDI, DAGHFOUS, FOURATI et al., 2013; BAHARUDIN, ROHAIDA and KHAIRUDIN, 2012).

It is important to note that styloid processes with a length greater or equal to $25 \mathrm{~mm}$ can be associated with clinical manifestations such as craniofacial or cervical pain, dysphagia, sore throat, drooling, foreign body sensation, limited mouth opening and limited movements of the head and neck, dizziness, and in severe cases, vascular symptoms. These symptoms were characterized in 1937 and in 1949 as Eagle syndrome, which can manifest itself in two different ways: The classic syndrome which is mostly associated to patients who had a previous tonsillectomy and is characterized by spastic and persistent

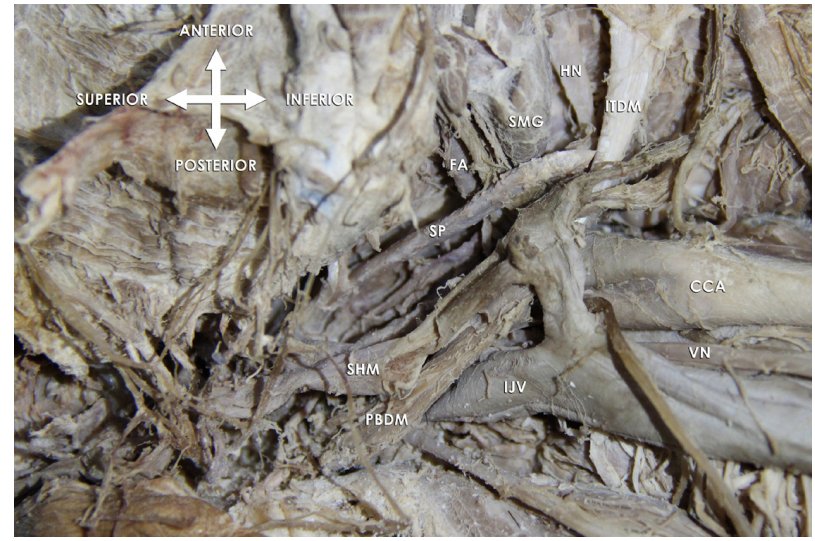

Figure 1. Lateral view of the right cervical region, at the level of the submandibular triangle. The styloid process (SP) is observed to extend toward the intermediate tendon of the digastric muscle (ITDM), posteriorly to the submandibular gland (SMG), and laterally to the facial artery (FA) and hypoglossal nerve (HN). The stylohyoid muscle (SHM) and the posterior belly of the digastric muscle (PBDM) are also shown parallel and posterior to the SP. The anatomical association of the SP to the bifurcation of the right common carotid artery (CCA), the vagus nerve (VN), and the right internal jugular vein (IJV) are also depicted. Source: Authors.

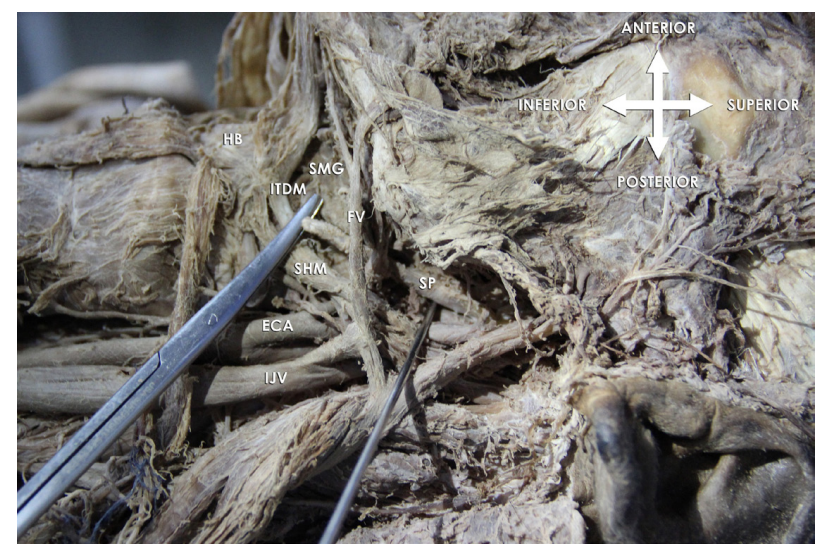

Figure 2. Lateral view of the left cervical region, at the level of the submandibular triangle. The route of the styloid process (SP) is displayed following its projection from its origin at the base of the skull. It extends posteriorly and inferiorly to the submandibular gland (SMG) and proceeds to approach the intermediate tendon of the digastric muscle (ITDM). The insertion of the digastric muscle on the lesser cornu of the hyoid bone (HB) is also shown. Anatomical relationships corresponding with vasculature include the external carotid artery (ECA), the internal jugular vein (IJV) and the facial vein (FV), as well as its anterior association with the stylohyoid muscle (SHM) are also depicted. Source: Authors.

pain in the throat, salivation and nausea. The stylocarotid syndrome in which there is compression of the carotid arteries by the elongated styloid process and it may be associated or not to surgical history in proximity to the styloid process. This is characterized by sore throat, headache and dizziness, which are enhanced by movements of the head (BOUZAIDI, DAGHFOUS, FOURATI et al., 2013; CULLU, DEVEER, SAHAN et al., 2013; KHANDELWAL, HADA and HARSH, 2011; HAN, KIM and YANG, 2013). 
BAENA-CALDAS, G. P., ROJAS-ZULUAGA, S. and PECKHAM, X.

Table 1. Average lengths of all styloid processes described in previous studies compared to the current study.

\begin{tabular}{lccc}
\hline \multicolumn{1}{c}{ Author and year of publication } & Country & X \pm SD & Sample \\
\hline $\begin{array}{l}\text { Da Silva, Moraes and Tashiro (2002) } \\
\text { Andrei, Motoc, Didilescu et al. (2013) }\end{array}$ & Brasil & $33.72 \pm 6.33$ & 15 cadavers' hemifaces \\
Cullu, Deveer, Sahan et al. (2013) & Turkey & $35.09 \pm 8.9$ & $\begin{array}{c}44 \text { cone beam computed } \\
\text { tomography }\end{array}$ \\
Current study & Colombia & $35.11 \pm 13.23$ & $\begin{array}{c}160 \text { multidetector computed } \\
\text { tomography } \\
46 \text { cadavers' hemifaces }\end{array}$ \\
\hline
\end{tabular}

Table 2. Average length of styloid processes considered "elongated" in previous studies compared to the current study.

\begin{tabular}{lccc}
\hline \multicolumn{1}{c}{ Author and year of publication } & Country & $\mathbf{X} \pm$ SD & Sample \\
\hline $\begin{array}{l}\text { Fuentes-Fernándes, Oporto-Venegas, } \\
\text { Garay-Carrasco et al. (2007) }\end{array}$ & Chile & $49.39 \pm 9.17$ & 968 panoramic X-rays \\
$\begin{array}{l}\text { Sudhakara-Reddy, Sai-Kiran, } \\
\begin{array}{l}\text { Sai-Madhavi et al. (2013) } \\
\text { Current study }\end{array}\end{array}$ & India & $36.7 \pm 6.2$ & 260 panoramic X-rays \\
\hline
\end{tabular}

Both conditions can be confused with other disorders such as glossopharyngeal neuralgia, cervical pain, cerebrovascular events or temporomandibular joint disorders, among others. It should be noted that not all elongated processes are symptomatic. Chaves et al. in Chile reported a case of a 79 year old woman with styloid processes $75.85 \mathrm{~mm}$ and $80.96 \mathrm{~mm}$ in length as an incidental radiological finding, without any symptoms (CHAVES, COSTA, CAVALCANTE et al., 2013). Epidemiologically, it has been found that only $4 \%$ of the general population with an elongated styloid process is diagnosed with Eagle syndrome (BOUZAIDI, DAGHFOUS, FOURATI et al., 2013; CULLU, DEVEER, SAHAN et al., 2013; KHANDELWAL, HADA and HARSH, 2011). The authors of this study believe that one of the possible explanations is the direction and angulation of the process in the three planes of space and its consequent relationship to adjacent anatomical structures.

The pathophysiology of the syndrome has been associated with 5 components: 1) History of trauma on the styloid process i.e. as a result of fracture or iatrogenic trauma in surgical procedures such as tonsillectomy. This may lead to proliferation of granulation tissue causing pressure on adjacent structures; 2) Compression of the glossopharyngeal nerve, the mandibular branch of the trigeminal nerve and/or the chorda tympani; 3) Tendinitis caused by local inflammatory processes; 4) Irritation of the pharyngeal mucosa by direct compression or tonsillectomy and direct lesion to the trigeminal, facial, glossopharyngeal and vagus; 5 ) Irritation of the sympathetic nerves of the carotid plexus (MOON, LEE, KWON et al., 2014; BOUZAIDI, DAGHFOUS, FOURATI et al., 2013; CULLU, DEVEER, SAHAN et al., 2013).

There is also evidence of cases not associated with trauma, as reported by Permpalung, Suksaranjit, Chongnarungsin et al. (2014) in the United States. The patient had Eagle's syndrome triggered by acute mumps and the styloid process length measured by computed tomography was $53 \mathrm{~mm}$ (CHAVES, COSTA, CAVALCANTE et al., 2013). In reviewing existing studies on Eagle syndrome there are basically two patterns of published studies. Some studies did an analysis of all pieces of obtained data, while other studies only analyzed the cases in which the styloid processes were greater than $30 \mathrm{~mm}$ in length, thus were considered elongated. In our study, both patterns of study were followed in order to compare our data with data reported in the literature. Table 1 summarizes the averages of lengths of all styloid processes measured in several studies. The results obtained in our study were similar to those found by Da Silva, Moraes and Tashiro (2002) in Brazil and by Andrei, Motoc, Didilescu et al. (2013) in Romania. Table 2 shows the data of length averages of styloid processes considered "elongated" reported in the literature. The results of our study are comparable to those reported by Fuentes-Fernándes, Oporto-Venegas, Garay-Carrasco et al. (2007) in Chile.

\section{Conclusion}

Understanding the frequency of occurrence of a variation in a specific population is an important consideration when facing challenging differential diagnoses. Our results show a frequency comparable to previous studies. In our study, $50 \%$ of the hemifaces had a styloid process that could be considered as "elongated".

Given that the occurrence of symptoms is variable and sometimes independent of the length of the styloid process, we suggest the angulation of the styloid process as a factor even more relevant that the length itself. Future careful examination of the angulation and the relationship to anatomical structures with radiological imaging would play an important role in the clinical evaluation of patients with a better understanding of the etiology of symptoms based on its anatomical relationships.

In this study we discuss the anatomy and embryology of the styloid process as well as the pathophysiology of Eagle syndrome.

Knowing the frequency of an anatomical variation in a specific population is an important consideration when analyzing conditions with multiple differential diagnoses. In the present study, $50 \%$ of hemifaces had a styloid process that could be considered as "elongated", with a prevalence comparable to previous studies. Since previous reports have shown that the onset of symptoms is variable and sometimes independent of the length of the styloid process, we suggest that the angulation 
of the styloid process is a factor as important as its length. A better understanding of the anatomic relationships of the styloid process as a result of its angulation would provide a better understanding of the etiology of symptoms and subsequently would allow an appropriate therapeutic approach for patients with Eagle syndrome. Therefore, we consider important to perform a careful analysis of the angulation of the styloid process and its relationship to adjacent anatomical structures through imaging studies.

Acknowledgements: We want to thank the Department of Morphology, Universidad del Valle for facilitating the cadavers that were studied. Thanks to Jorge Ernesto Ávila for processing the images used in the present study.

\section{References}

ANDREI, F., MOTOC, AG., DIDILESCU, AC. and RUSU, MC. A 3D cone beam computed tomography study of the styloid process of the temporal bone. Folia Morphologica, 2013, vol. 72, n. 1, p. 2935. PMid:23749708. http://dx.doi.org/10.5603/FM.2013.0005.

BAHARUDIN, A., ROHAIDA, I. and KHAIRUDIN, A. Transoral surgical resection of bilateral styloid processes elongation (eagle's syndrome). Acta Informatica Medica, 2012, vol. 20, n. 2, p. 133-135. PMid:23322967. http://dx.doi.org/10.5455/aim.2012.20.133-135.

BOUZAIDI, K., DAGHFOUS, A., FOURATI, E., KECHAOU, I., JABNOUN, F. and CHTIOUI, I. Eagle's syndrome. Acta Radiologica Short Reports, 2013, vol. 2, n. 5, p. 2047981613495676. PMid:24198961. http://dx.doi.org/10.1177/2047981613495676.

CHAVES, H., COSTA, F., CAVAlCANTE, D., RiBEIRO, T. and GONDIM, D. Asymptomatic bilateral elongated and mineralized stylohyoid complex: report of one case. Revista Medica de Chile, 2013, vol. 141, n. 6, p. 793-796. PMid:24121584. http://dx.doi. org/10.4067/S0034-98872013000600015.

CHOURDIA, V. Elongated styloid process (Eagle's syndrome) \& severe headache. Indian J Otolaryngol Head Neck Surg, 2002, vol. 54, n. 3, p. 238-241. PMid:23119903.

CUllu, N., DEVEER, M., SAHAN, M., TETIKER, H. and YILMAZ, M. Radiological evaluation of the styloid process length in the normal population. Folia Morphologica, 2013, vol. 72, n. 4, p. 318321. PMid:24402753. http://dx.doi.org/10.5603/FM.2013.0053.

DA SILVA, H. J., MORAES, S. R. A. \& TASHIRO, T. Análisis morfométrico de los elementos de la cadena estilohioídea. Revista Chilena de Anatomia, 2002, vol. 20, p. 205-210.
ELIMAIRI, I., BAUR, DA., ALTAY, MA., QUERESHY, FA. and MINISANDRAM, A. Eagle's Syndrome. Head and Neck Pathology, 2015, vol. 9, n. 4, p. 492-495. PMid:25537830. http://dx.doi. org/10.1007/s12105-014-0599-4.

FUENTES-FERNÁNDES, R., OPORTO-VENEGAS, G., GARAYCARRASCO, I., BUSTOS-MEDINA, L., SILVA-MELLA, H. and FLORES FLORES, H. Proceso estiloides en una muestra de radiografías panorámicas de la ciudad de Temuco-Chile. International Journal of Morphology, 2007, vol. 25, n. 4, p. 729-733. http://dx.doi. org/10.4067/S0717-95022007000400010.

HAN, MK., KIM, W. and YANG, JY. Non surgical treatment of Eagle's Syndrome: a case report. The Korean Journal of Pain, 2013, vol. 26, n. 2, p. 169-172. PMid:23614080. http://dx.doi.org/10.3344/ kjp.2013.26.2.169.

KHANDELWAL, S., HADA, YS. and HARSH, A. Eagle's syndrome: a case report and review of the literature. The Saudi Dental Journal, 2011, vol. 23, n. 4, p. 211-215. PMid:23960519. http://dx.doi. org/10.1016/j.sdentj.2010.10.006.

MAYRINK, G., FIGUEIREDO, EP., SATO, FR. and MOREIRA, RW. Cervicofacial pain associated with Eagle's syndrome misdiagnosed as trigeminal neuralgia. Oral and Maxillofacial Surgery, 2012, vol. 16, n. 2, p. 207-210. PMid:21720752. http://dx.doi.org/10.1007/ s10006-011-0276-7.

MOON, CS., LEE, BS., KWON, YD., CHOI, BJ., LEE, JW., LEE, HW., YUN, SU. and OHE, JY. Eagle's syndrome: a case report. Journal of the Korean Association of Oral and Maxillofacial Surgeons, 2014, vol. 40, n. 1, p. 43-47. PMid:24627843. http://dx.doi. org/10.5125/jkaoms.2014.40.1.43.

PERMPALUNG, N., SUKSARANJIT, P., CHONGNARUNGSIN, D. and HYMAN, CL. Unveiling the hidden eagle: acute parotitisinduced eagle syndrome. North American Journal of Medical Sciences, 2014, vol. 6, n. 2, p. 102-104. PMid:24696832. http://dx.doi. org/10.4103/1947-2714.127753.

SUDHAKARA-REDDY, R., SAI-KIRAN, C., SAI-MADHAVI, N., RAGHAVENDRA, MN. and SATISH, A. Prevalence of elongation and calcification patterns of elongated styloid process in south India. Journal of Clinical and Experimental Dentistry, 2013, vol. 5, n. 1, p. e30-e35. PMid:24455048. http://dx.doi.org/10.4317/jced.50981.

Received December 10, 2016 Accepted February 20, 2017 